1975

\title{
Archaeological Survey of Portions of the Comal River Watershed, Comal County, Texas
}

Thomas R. Hester

Center for Archaeological Research

Feris A. Bass, Jr.

Thomas C. Kelly

Follow this and additional works at: https://scholarworks.sfasu.edu/ita

Part of the American Material Culture Commons, Archaeological Anthropology Commons, Environmental Studies Commons, Other American Studies Commons, Other Arts and Humanities Commons, Other History of Art, Architecture, and Archaeology Commons, and the United States History Commons

Tell us how this article helped you.

This Article is brought to you for free and open access by the Center for Regional Heritage Research at SFA ScholarWorks. It has been accepted for inclusion in Index of Texas Archaeology: Open Access Gray Literature from the Lone Star State by an authorized editor of SFA ScholarWorks. For more information, please contact cdsscholarworks@sfasu.edu. 


\section{Archaeological Survey of Portions of the Comal River Watershed, Comal County,}

Texas

\section{Creative Commons License}

\section{(c) (1) (9)}

This work is licensed under a Creative Commons Attribution-NonCommercial 4.0 International License 
ARCHAEOLOGICAL SURVEY OF PORTIONS OF

THE COMAL RIVER WATERSHED, COMAL COUNTY, TEXAS

Thomas R. Hester, Feris A. Bass, Jr. and Thomas C. Kelly

The Center for Archaeological Research

The University of Texas at San Antonio Archaeological Survey Report No. 6

$$
\text { January 5, } 1975
$$


TABLE OF CONTENTS

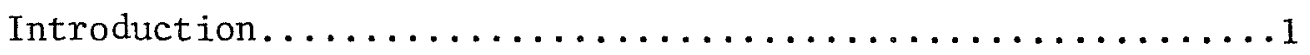

Archaeological Background.....................

Survey Procedures.........................

Results of the Survey......................

Summary and Recommendations................... 21

References Cited............................. 5

Appendix I

A Bibliography of Comal County Archaeology..........26

Appendix II

Men Dig Up Eight Skeletons While Excavating Ditches....28 


\section{LIST OF FIGURES}

Figure 1. Locations of Sites in Floodwater Retarding Structure No. $1 \ldots \ldots \ldots \ldots \ldots \ldots \ldots \ldots \ldots \ldots \ldots \ldots \ldots \ldots$

Figure 2. Locations of Sites in Floodwater Retarding

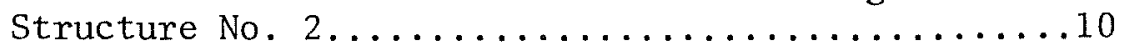

Figure 3. Artifacts from Floodwater Retarding Structure

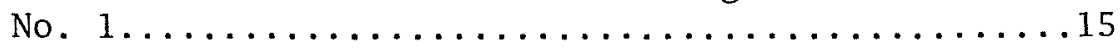

Figure 4. Artifacts from Floodwater Retarding Structure

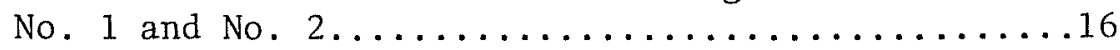

Figure 5. Artifacts from Floodwater Retarding Structure

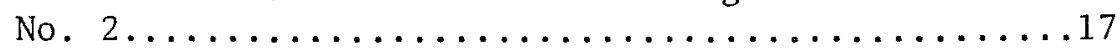

Figure 6. Artifacts from Floodwater Retarding Structure

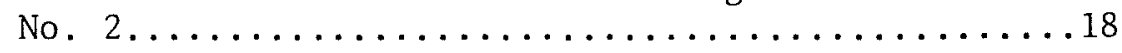

Figure 7. Artifacts from Floodwater Retarding Structure

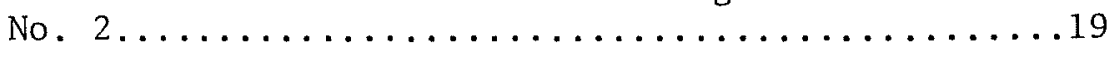

Figure 8. Artifact from Floodwater Retarding Structure

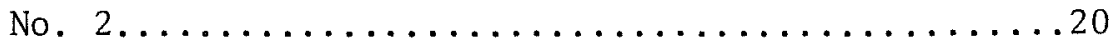




\section{INTRODUCTION}

In November, 1974, an archaeological survey was carried out in portions of the Comal River Watershed, Comal County, Texas (Figs. 1, 2). These investigations resulted from an agreement (427SCS-TX-75) between the U.S.D.A. Soil Conservation Service and the Center for Archaeological Research, The University of Texas at San Antonio. Fieldwork was conducted by personnel of the Center, under the supervision of $\mathrm{Dr}$. Thomas R. Hester. The Soil Conservation Service proposes to construct two floodwater retarding structures in the Comal River Watershed: Floodwater Retarding Structure No. 1 will encompass 276 acres (112 hectares), while 558 acres (226 hectares) will be involved in the construction of Structure No. 2. In order to assess the archaeological and historical resources within the two project areas, the survey teams carried out their field studies following these five guidelines:

1. Determine if such archeological resources exist within the areas committed to installation of each floodwater retarding structure.

2. If resources are found, record, identify, and appraise the significance of resources.

3. Evaluate the impact of project installation on each resource.

4. Provide and result in recommendations for mitigation of adverse impacts anticipated.

5. Provide estimate of costs required for mitigation (sa1vage, protection, etc.). 
ARCHAEOLOGICAL BACKGROUND

Very little scientific archaeology has been done in Comal County. The most extensive research to date was the archaeological salvage program in the Canyon Reservoir area, carried out in 1959-1960 by The University of Texas at Austin (Johnson, Suhm and Tunne11, 1962). Excavations were conducted at three major sites: Oblate rockshelter, Wunderlich, and Footbridge. Additional work was accomplished in the Canyon Reservoir basin by the Texas Archeological Society in 1963 (particularly at Oblate rockshelter; this work remains unpublished, although there have been notices by Davis 1963, 1964). We have listed in Appendix I of this report a number of published and unpublished studies dealing with the archaeology of Canyon Reservoir and other areas of Coma1 County.

Based on the Canyon Reservoir research, Johnson, Suhm and Tunnel1 (1962: Fig. 45) have proposed the following divisions in the region's prehistory: Paleo-Indian (roughly 9200-6000 B.C.); Archaic (ca. 6000 B.C. to A.D. 500/1000); Neo-American (or late prehistoric; approximately A.D. 500/1000-1600). Each of these major time periods is characterized by specific kinds of artifacts, and changes through time are recognized by alterations in projectile point styles.

Major types of prehistoric archaeological sites in Comal County include a] open occupation sites (both temporary and repeatedlyused sites, often situated along stream courses and low stream 
hammerstones, crude bifaces (Fig. 4, B), cores, one finely

worked biface, and preforms (see Fig. 4, A). There is little in the way of flaking debris and the field team believes that the materials may be redeposited.

\section{Site $41 \mathrm{CM} 60$}

This site is along the creek at the northern end of the proposed reservoir. Most of the site seems to be above the $900 \mathrm{ft}$ $(274 \mathrm{~m})$ contour level and out of the purview of this survey. However, the formerly cultivated fields of Speck Redland soil bear scattered indications of prehistoric occupation.

Because of the sparsity of archaeological remains and previous soil disturbance, no further work is recommended.

\section{Floodwater Retarding Structure No. 2}

This proposed floodwater retarding structure is located on Dry Comal Creek approximately nine $\mathrm{km}$ due west of New Braunfels, Texas. Dry Comal Creek is a relatively large, intermittently flowing stream, widening at points within the proposed construction area to a dimension of approximately $90 \mathrm{~m}$.

There are a number of apparently permanent water pools along the course of the stream bed. The water course is bounded along the course of the stream bed by rolling hills that, due to stream cutting, form bluffs immediately adjacent to the channel. 
This page has been

redacted because it

contains restricted

information. 
The vegetation in the area at the time of this survey was in the process of fall defoliation, and this facilitated our inspection. There were signs, however, that during the immediately preceeding period an extremely heavy vegetation cover had been present.

The type of vegetation that was almost continuously present for the entire length of the area inspected was live oak, elm and cedar trees with a relatively light stand of grass. On some alluvial deposits immediately adjacent to the stream bed, a heavy cover of Bermuda grass was often observed. In these latter areas there were often heavy stands of sunflowers and other weedy plants.

Except for a few areas of thick alluvial deposits along the stream bed, the terrain was generally underlain by a practically continuous limestone formation with numerous chert outcroppings. The survey of the site for this structure was conducted by Feris A. Bass, Jr. and Jules Jaquier. The survey of the entire 226 ha was conducted on foot with both surveyors moving up one side of the stream course and returning on the other.

It became apparent quite early in the survey that this had been an area heavily and frequently utilized by prehistoric peoples. The areas adjacent to both sides of the stream bed for the entire distance covered by the proposed project had been exploited as chert quarries and workshops. The heavy concentration of 
chert cores, flakes, biface preforms throughout the reservoir would suggest that the whole area might be considered as one large "site". We have assigned site numbers to these large localities (41CM65, 41CM67, 41CM68, 41CM69), although further, more intensive work might result in the delineation of additional sites. There were also three discrete sites consisting of burned rock middens and other features that are described below.

Site $41 \mathrm{CM} 62$

This site, is situated on a bluff overlooking a permanent waterhole on the Dry Comal Creek. The site is a burned rock midden approximately $30 \mathrm{~m}$ in diameter and approximately $45 \mathrm{~cm}$ deep. The deposit overlies a sterile limestone-caliche base. The site is covered with live oak and cedar, as we11 as a light grass cover. A small shovel test produced bone fragments, a point fragment at $30 \mathrm{~cm}$ and a uniface (scraper?) at $44 \mathrm{~cm}$. Chert chips and fragments were generally distributed at all levels. The location of this site at the central part of the surrounding workshop area and adjacent to permanent water would indicate the advisability of further investigation.

\section{Site $41 \mathrm{CM} 63$}

This site is on the slope of a ridge at the south end of the proposed dam construction site. It is primarily a burned rock 
midden which is weathering out on the slope leading down into the stream bed. There is a large quantity of burned rock, much of which seems to have been burned in place. There is also a heavy concentration of chert artifacts, flakes and chips covering this area. The site is approximately $50 \mathrm{~m}$ wide and $150 \mathrm{~m}$ long, and is covered with a heavy stand of live oak and cedar trees. We recommend that this site receive additional intensive survey and test excavation in order to evaluate its significance.

\section{Site $41 \mathrm{CM} 64$}

This is a small burned rock midden located on a low rise on the west bank of the Dry Comal Creek. It is on a second stream terrace which is grass covered with some brushy growth and has numerous limestone croppings. A smal1 test pit dug to a depth of $30 \mathrm{~cm}$ revealed some burned rock, and a scattering of chert flakes. Additional testing and intensive surface survey would aid in evaluating the importance of the site.

\section{$41 \mathrm{CM} 65-41 \mathrm{CM} 69$}

Throughout most of the reservoir area, both sides of Dry Comal Creek were characterized by extensive lithic debris attributable to workshop activities. As mentioned earlier, there may be numerous sites represented by the archaeological remains, but in our brief inspection, we were able only to distinguish five major concentrations or localities. We have 
assigned the following site numbers to these areas: 41CM65, 41CM66, 41CM67, 41CM68, 41CM69.

These localities vary in size from $500 \times 100 \mathrm{~m}$ (41CM66) to areas over one $\mathrm{km}$ in length and $100 \mathrm{~m}$ in width (41CM65, 41CM67). Limited samples were collected. Artifacts include roughly flaked bifaces (many of which are broken), bifacial preforms, partially-bifaced tabular cobbles, cores, and flakes (many of which are quite large). Several specimens from these sites are illustrated in Figs. 4-8. 


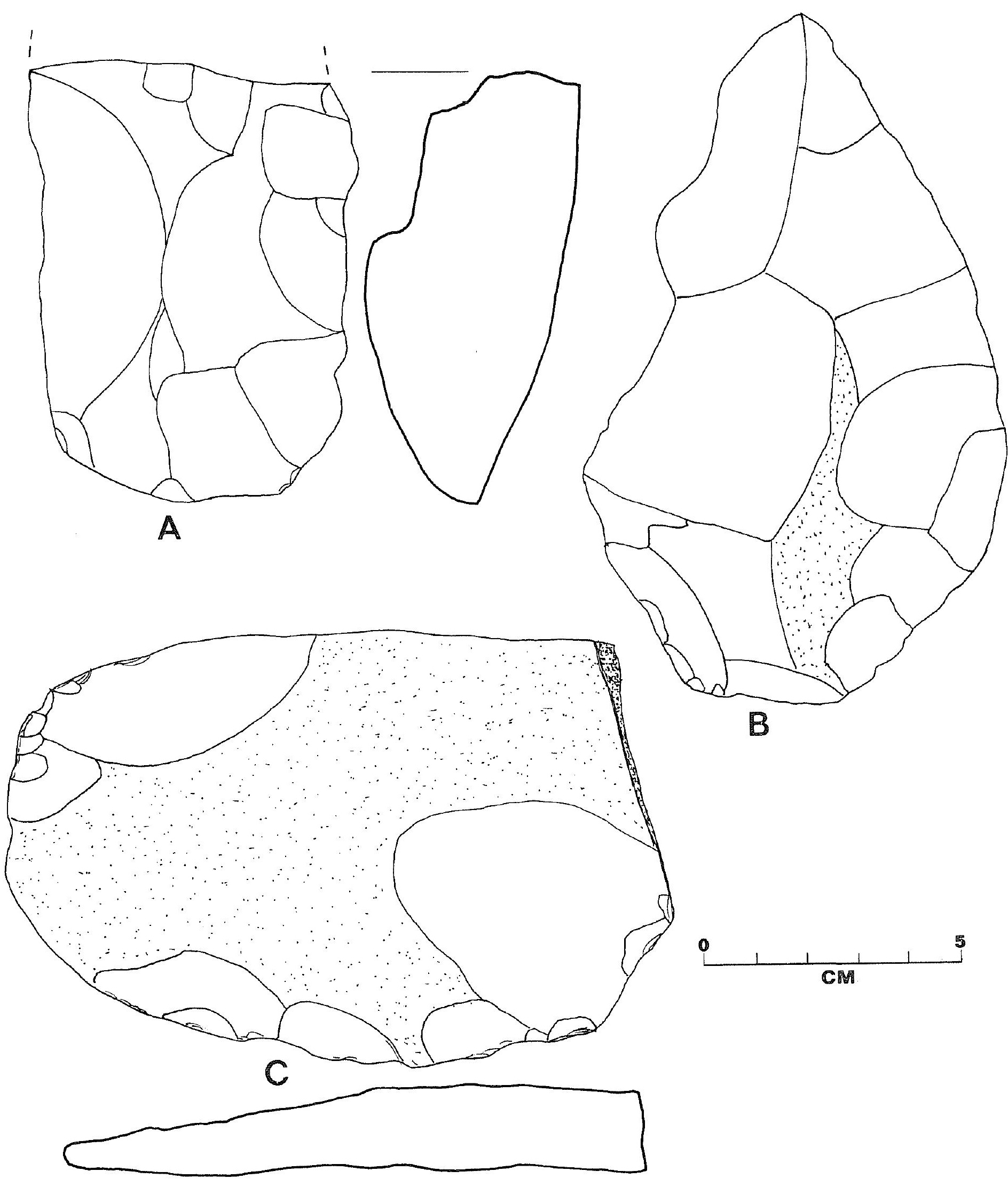

Figure 3. Artifacts from the area of Floodwater Retarding Structure No. 1.A, crude biface, 41CM56; B, biface, 41CM56; C, partially bifaced tabular cobble, 41CM58. 

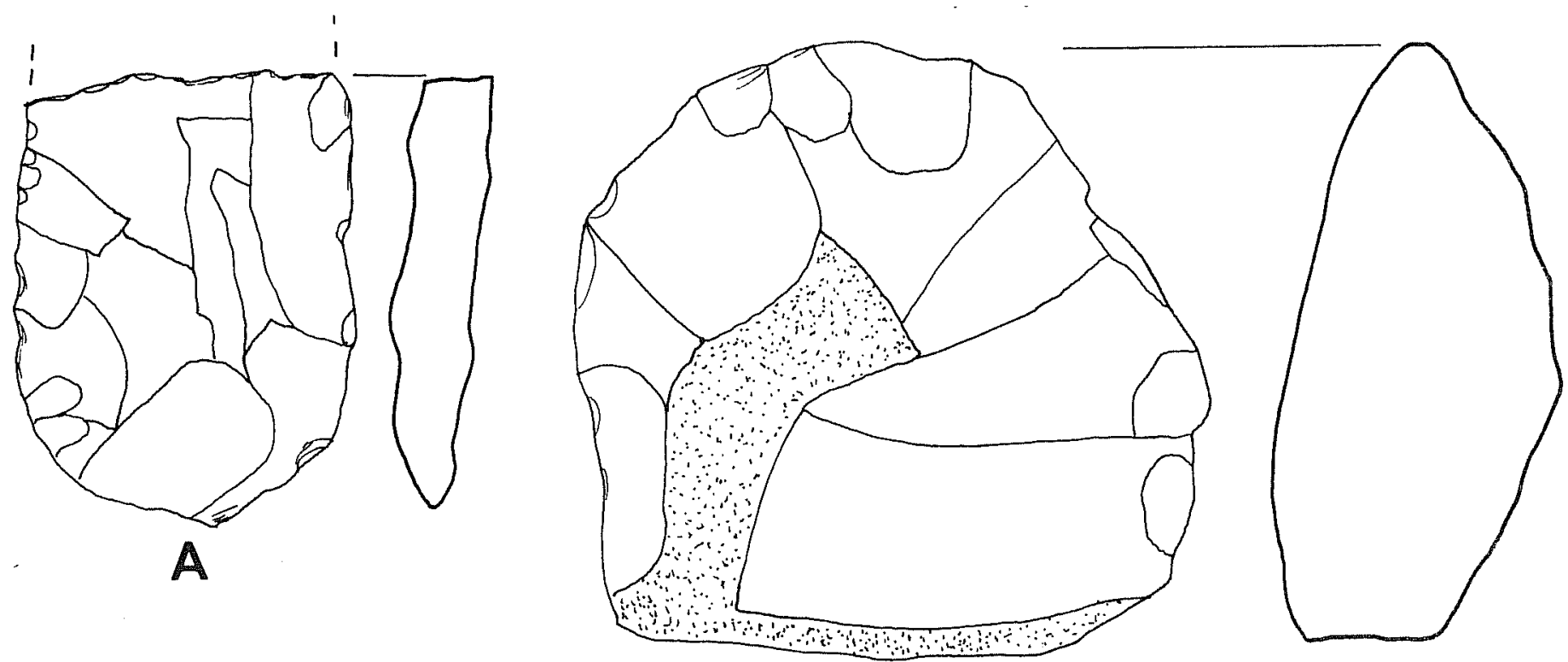

B
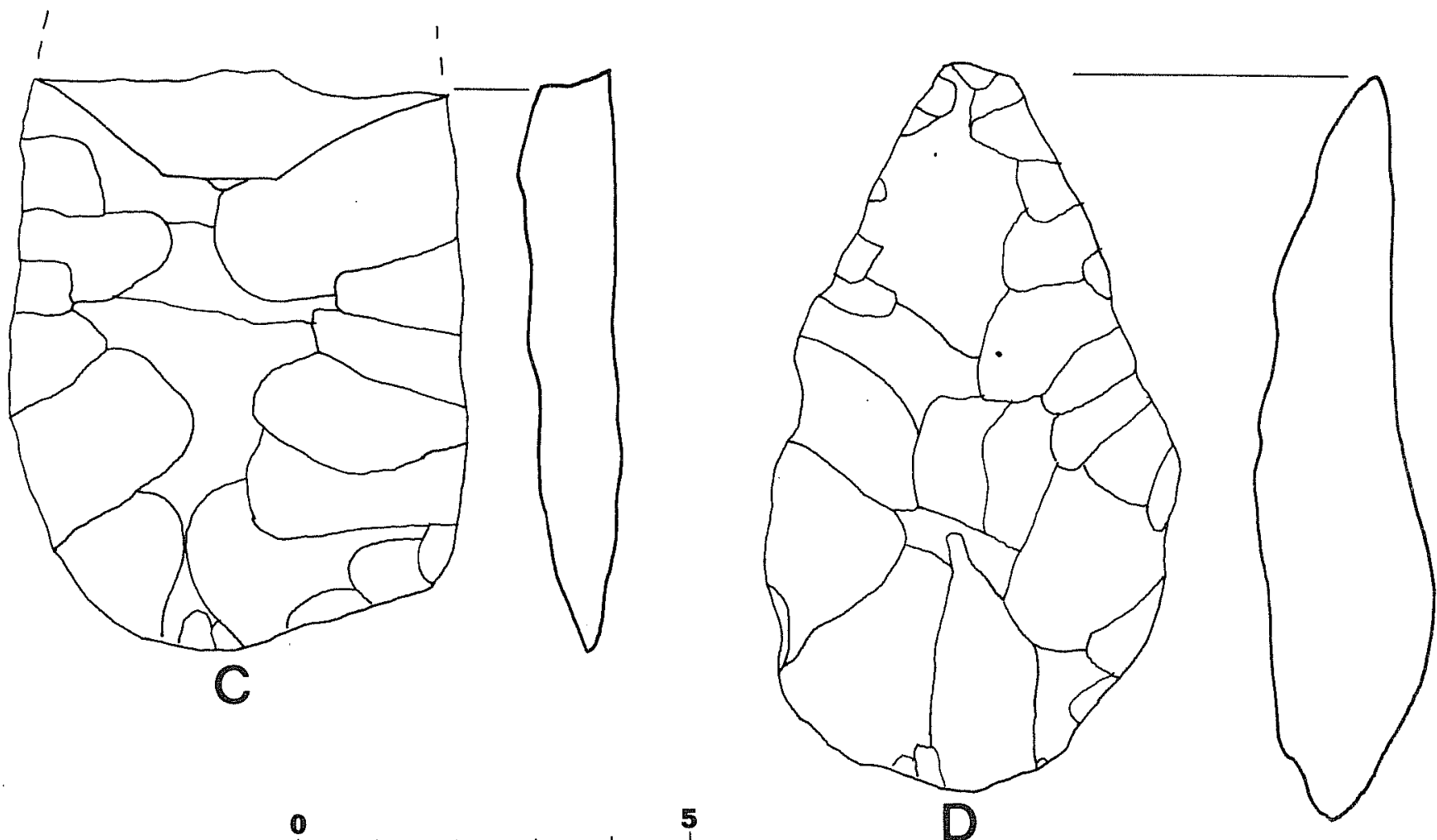

Figure 4. Artifacts from the areas of Floodwater Retarding Structures No. 1 and 2. A, bifacial preform, 41CM59; B, bifaced cobble, 41CM59; C, bifacial preform, 41CM65; D, bifacial preform, 41CM66. 

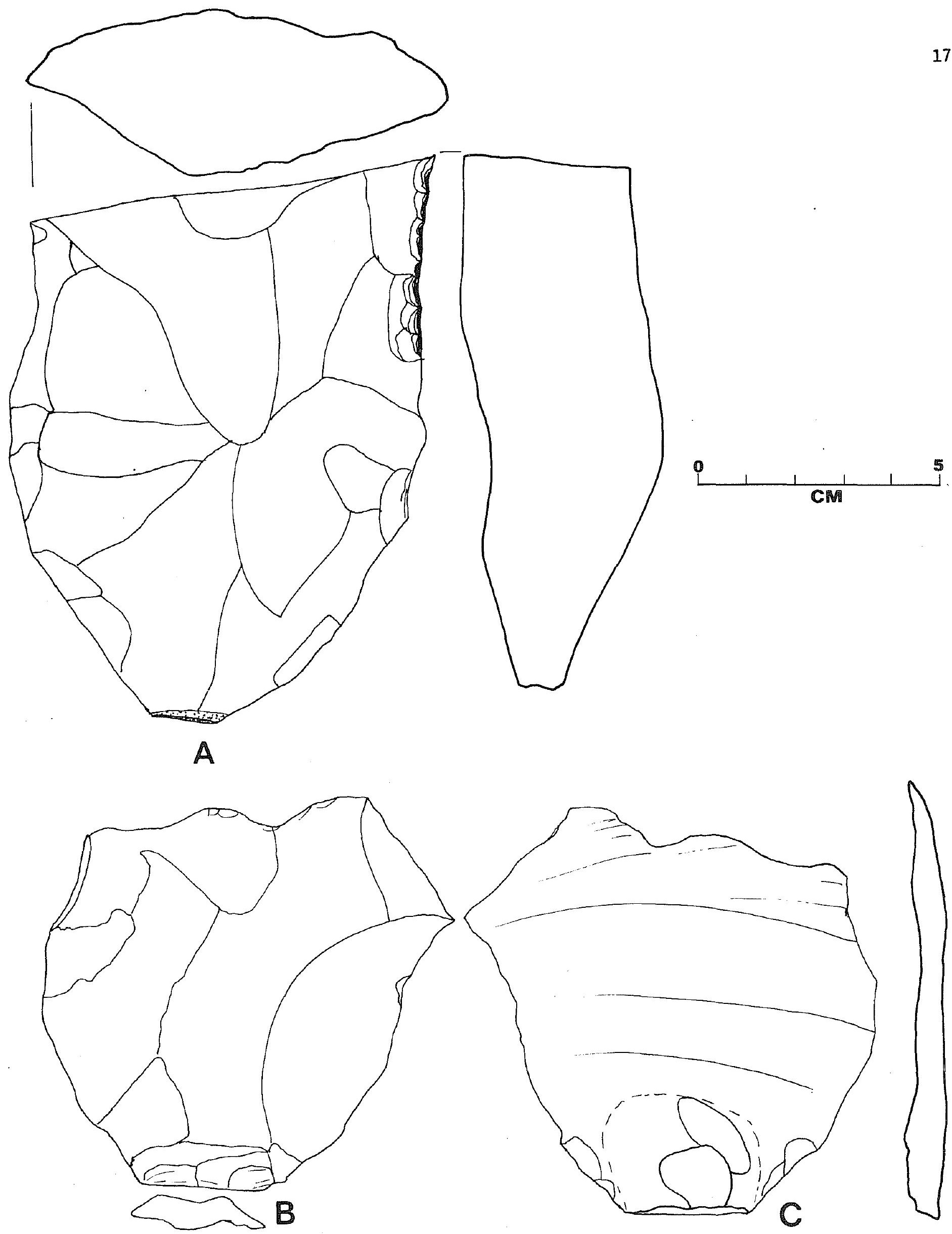

Figure 5. Artifacts from the area of Floodwater Retarding Structure No. 2. A, crude biface, 41CM66; B, C, both sides of large percussion flake, 41CM65 

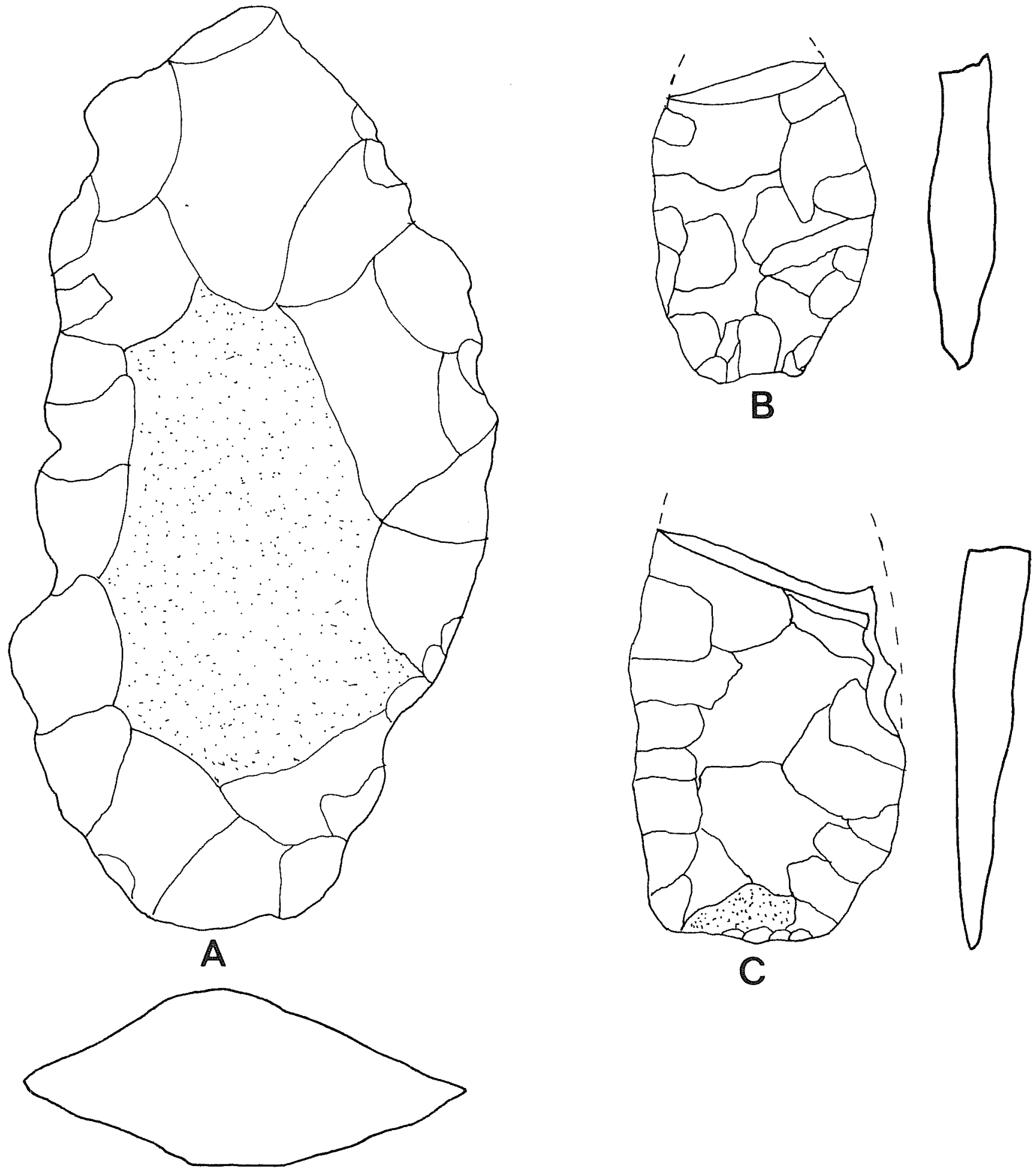

Figure 6. Artifacts from the area of.Floodwater Retarding Structure No. 2. A, large crude biface, 41CM65; B, C, bifacial preforms, $41 \mathrm{CM} 67$.

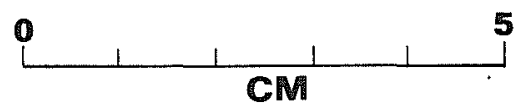



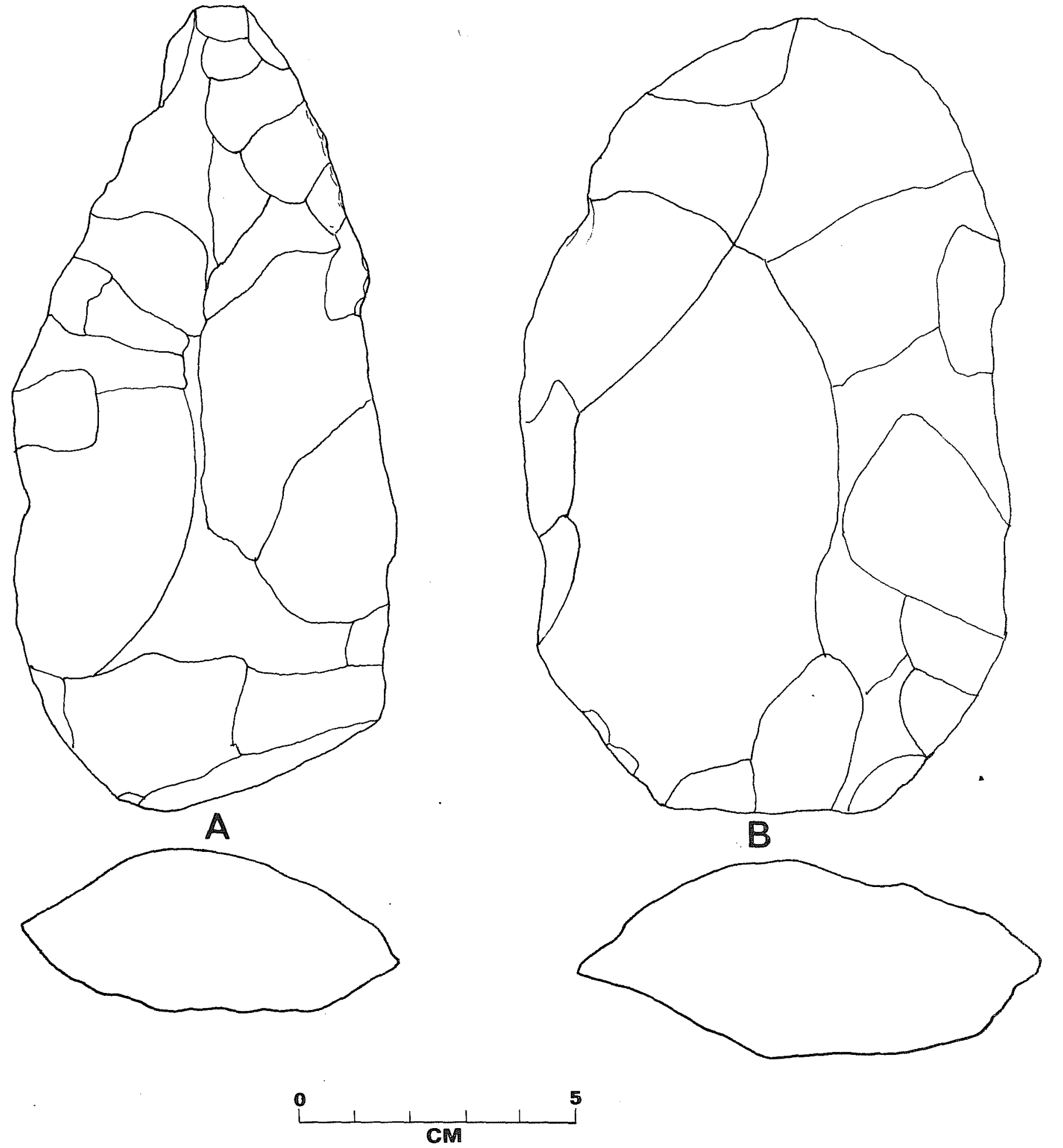

Figure 7. Artifacts from the Area of Floodwater Retarding Structure No. 2. A, B. crude bifaces, $41 \mathrm{CM} 68$. 

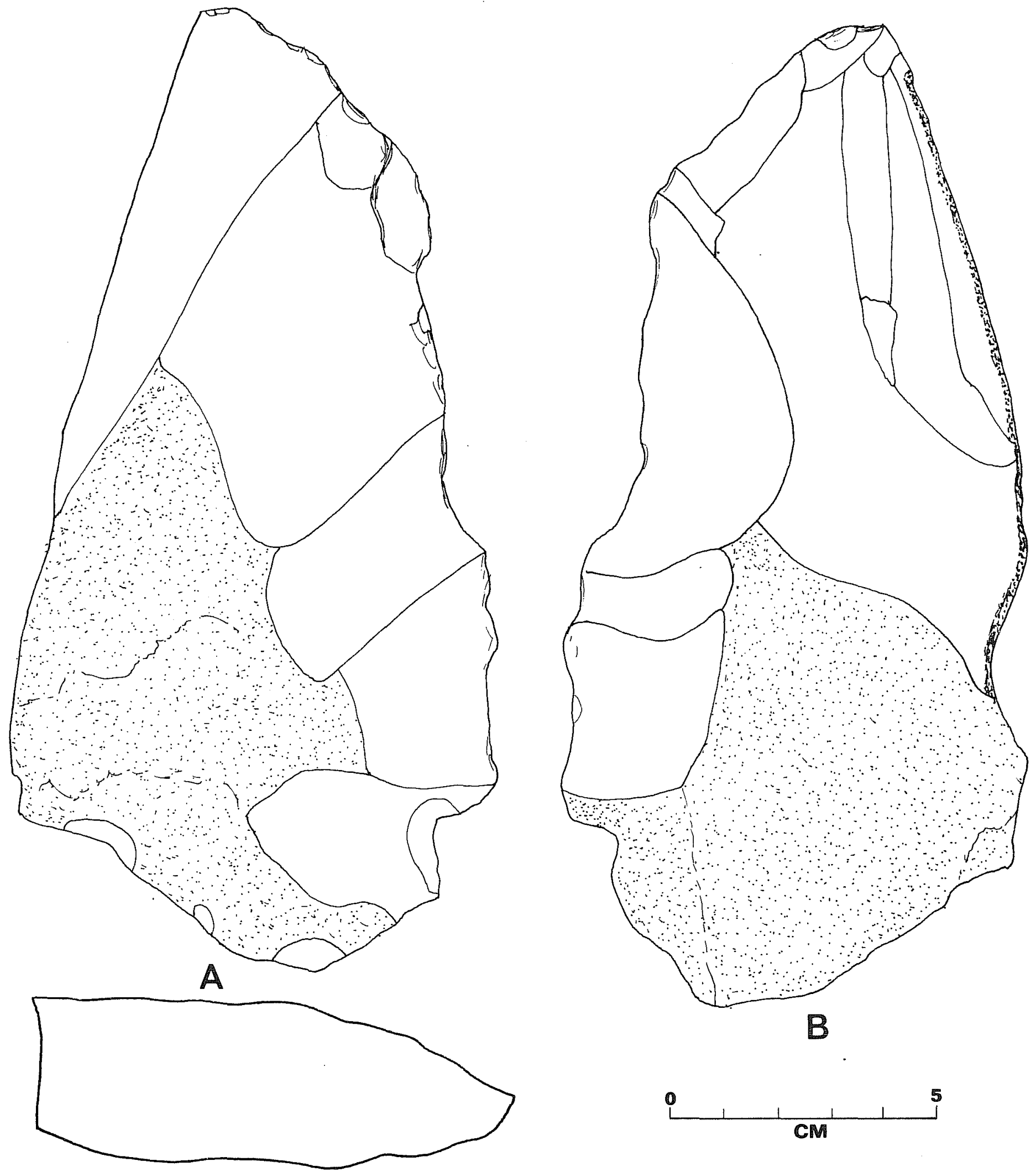

Figure 8. Artifact from the Area of Flocdwater Retarding Structure No. 2. A, B, both faces of large crude biface. 


\section{SUMMARY AND RECOMMENDATIONS}

An archaeological survey of portions of Dry Comal Creek and the West Fork of Dry Coma1 Creek (within the Coma1 River Watershed) has led to the documentation of 14 prehistoric sites. The most common sites found in the area were the chert workshops. These workshop areas ("chipping stations") were present in both reservoirs and were, as one might expect, located in areas where chert nodules were exposed on the surface.

Six archaeological sites were found in the area of proposed Floodwater Retarding Structure No. 1. Two of the sites, 41CM61 and 41CM60 are apparently outside the boundaries of the project. Of the other four sites, two (41CM56 and 41CM59) have cultural materials which, if not secondary deposits, have at least been greatly disturbed; no further work is recommended at these two sites. Sites 41 CM58 and 41 CM57 are chert workshop sites, and we believe that further intensive survey and controlled surface collecting is necessary.

In Floodwater Retarding Structure No. 2, eight archaeological sites were recorded. Three sites were identified as burned rock middens (41CM62, 41CM63, 41CM64), apparent1y associated with occupation sites and, in the case of 41CM63, with a chert workshop. The remaining five sites (41CM65-41CM59) are very extensive chert workshops. The surfaces of these sites are littered with chert flakes, cores, crude bifaces, bifacial preforms, and other debris resulting from the tool manufacturing and raw material procurement processes. 
It is our recommendation that the three burned rock middens receive further attention in the form of intensive survey and test excavation. This is particularly desirable in the case of 41CM63, located in the vicinity of proposed dam site construction. These sites apparently date from the Archaic period (probably Middle Archaic; Hester 1971), but on1y one site of this sort has received scientific attention in the Comal County area (Johnson, Suhm and Tunnell 1962).

We further suggest that the chert workshops receive additional attention. These are probably the most significant cultural resources in the area of Floodwater Retarding Structure No. 2. These sites represent a facet of prehistory sorely neglected in previous Central Texas archaeological research. Intensive survey and controlled surface collecting will allow a better assessment of the value of the sites in studies of primitive technology in the region. These workshops are located along the stream channe1, we11 within the detention pool and will thus be subjected to periodic inundation, once the project is completed.

Because of the time limits imposed on our survey, we could make only a cursory assessment of the burned rock middens and chert workshops in Floodwater Retarding Structure No. 2. In addition, two sites in Floodwater Retarding Structure No.1 (41CM57 and 41CM58) need further examination. We therefore propose further archaeological work in these two proposed project areas, and suggest that the work be accomplished in the following two phases: 
Phase I: Intensive survey and controlled surface collecting of the chert workshops in both floodwater retarding structures; additionally, intensive survey and test pitting, should be carried out at the three burned rock midden sites (41CM62, 41CM63, 41CM64). The results of Phase I would permit archaeologists to better define the character and boundaries of the chert workshops, and to assess the importance of these sites and the burned rock middens. Such assessments are needed if we are to decide what sites, if any, should be nominated to the National Register of Historic Places.

Phase II: Additional investigations designed to salvage archaeological resources in the areas proposed for the floodwater retarding structure would be required only if the need is demonstrated through the fieldwork carried out in Phase I. Mitigation under Phase II might include ful1scale excavations of the burned rock midden sites and further controlled collecting of the chert workshops.

We are concerned here primarily with the recommended work outlined in Phase $I$. We do not believe that enough has been learned about the archaeology in these areas to allow us to make far-ranging recommendations for mitigation of adverse impacts which might be brought about by the projects. We firmly believe that more intensive survey would permit us to better evaluate the complex archaeological situation in the watershed. Phase I would require a field session of approximately one month and necessitate the services of a Research Archaeologist, one field 
assistant, one 1aboratory assistant, travel funds, supplies, University indirect costs, employee fringe benefits, and the expense of report preparation. Our preliminary cost estimate for Phase $I$ is $\$ 3,800.00$.

The cost of mitigation (if required) under Phase II would depend on the findings of the Phase I investigation. 
REFERENCES CITED

Davis, E.M.

1963 The T.A.S.-T.C.A.S.-U.T. Summer Dig. Texas Archeology 7 (2): 6-7.

1964 The Oblate Dig: A Postscript. Texas Archeology 8 (1): 1 .

Haas, 0.

1963 Texas' Canniba1 Indian Tribe Encountered Here by Settlers. Early New Braunfels-XXVII. New Braunfels Herald, April 26.

Hester, T.R.

1971 Archeological Investigations at the La Sita Site, Uvalde County, Texas. Bulletin of the Texas Archeological Society 42: $51-148$.

Johnson, L., Jr., D.A. Suhm and C.D. Tunnel1

1962 Salvage Archeology of Canyon Reservoir: The Wunderlich, Footbridge and Oblate Sites. Texas Memorial Museum Bulletin 5 .

Patterson, P.E.

1974 Upper San Marcos River Watershed, Hays County, Texas: An Archeological Survey of Areas Proposed for Modification. Texas Archeological Survey, Research Report 42.

\section{ACKNOWLEDGEMENTS}

We are grateful to the following persons for their contributions to this project: Mr. Reuben McDonald (New Braunfels office, SCS), Mr. Logan Crews (Temple office, SCS), Col. E.S. Harris, Capt. Jules Jacquier, Lynn Highley, Nancy Y. Clayton (Center for Archaeological Research) and to Bonnie Ernest, who typed the report and handled administrative details. 
APPENDIX I

A BIBLIOGRAPHY OF COMAL COUNTY ARCHAEOLOGY*

Alexander, Herbert

ms. An Analysis of the Stone Flakes from the Oblate Site, Canyon

Reservoir. (Unpublished manuscript; Texas Archeological Research Laboratory files).

Anonymous (Robert E. Bell)

News-Meeting of the Texas Archeological Society. Oklahoma

Anthropological Society Newsletter 8(4): 3-7. 1959.

Collins, Michael B.

The Oblate Site, $41 \mathrm{CM} \mathrm{1,} \mathrm{Comal} \mathrm{County,} \mathrm{Texas:} 1963$ Excavations (unpublished report), in Texas Archeological Research Laboratory. 1966.

Davis, E. Mott

The T.A.S.-T.C.A.S.-U.T. Summer Dig. Texas Archeology $7(2): 6-7$.

1963 (Oblate rockshelter excavation).

The Oblate Dig: A Postscript. Texas Archeology 8(1): 1. 1964.

Hester, Thomas R., Feris Bass, Jr., and Thomas C. Kelly

Archaeological Survey of Portions of the Comal River Watershed, Comal

County, Texas. Center for Archaeological Research, The University of

Texas at San Antonio, Archaeological Survey Report, 6.1975.

Jackson, A.T.

The Fall Creek Sites. University of Texas Publication, 3802. 1938.

(Mention of Comal County).

Pendants and Their Uses. Bulletin of the Texas Archeological and Paleontological Society 13: 9-15. 1941. (Mention of Comal County).

Tubular Pipes and Other Tubes in Texas. Bulletin of the Texas Archeological and Paleontological Society. 12: 99-137. 1940.

Johnson, LeRoy Jr., Dee Ann Suhm, and Curtis Tunne11

1962: Salvage Archeology of Canyon Reservoir: The Wunderlich, Footbridge and Oblate Sites. Texas Memorial Museum Bulletin 5 .

*We are grateful to the Texas Archeological Research Laboratory for aid in compiling this bibliography. 
Kelley, Charles J.

Arrow or Dart Shaft Tools and Problematical Incised Stones from Central and Western Texas. E1 Palacio 55(3): 73-85. 1948. (Mention of Comal County).

New, Ina Claire The Race Against Water by UT Archeologists. The Alcalde 48(1): 12-15. 1959. (Canyon Reservoir salvage).

New Braunfels Herald

Men Dig Up Eight Skeletons While Excavating Ditches. New Braunfels Herald 38(32), July 26, 1929: 1,8. (Burials in Landa Park). Reprinted in Hester, Bass and Kel1y 1975.

Patterson, J.T. Boat-shaped Artifact of the Gulf Southwest States. University of Texas Bulletin 3732. 1937. (Mention of Comal County).

The Corner-tang Flint Artifacts of Texas. University of Texas Bulletin 3618. 1936. (Mention of Comal County).

Shafer, Harry $\mathrm{J}$. Archeological Survey of the Blieder's Creek Reservoir. Unpublished manuscript on file at the Texas Archeological Survey, University of Texas, Austin. n.d.

Stephenson, Robert L. Archaeological Survey of Canyon Reservoir on the Guadalupe River, Comal County, Texas. On file Smithsonian Institution River Basins Survey, Lincoln. 1949.

A Preliminary Survey of Canyon Reservoir, Comal County, Texas. Mimeographed Report of the River Basin Surveys, Smithsonian Institution, Austin Office. 1951.

River Basin Surveys in Texas. Plains Archeological Conference News Letter 2(4): 8-9. 1949 .

Wilson, Thomas

Arrowpolnts, Spearheads, and Knives of Prehistoric Times. Report of the United States National Museum 1897: 811-988, 1899. (Mention of Comal County). 
APPENDIX II

MEN DIG UP EIGHT SKELETONS WHILE EXCAVATING DITCHES

Believed to be more than fifteen centuries old*

While excavating ditches for sewers in the roadway near the entrance to Landa Park, workmen Saturday unearthed eight skeletons, pronounced to be those of ancient Indians.

Alb. Nowotny, local archaeologist, was advised of the find and assisted in excavating the bones, being able to save one complete skull of an Indian woman which he has restored and placed in his museum.

Eight skeletons were found in a space of fifteen feet, which had been buried with heads and feet alternating north and south, with the exception of the Indian woman who had been laid east and west and clasping a small child in her arms.

Arrowheads, trinkets and household implements of a very ancient form were found with the body of the woman and child, it being a custom of the ancient people to inter the personal belongings of the dead with the body, they believing that these items would be useful to the owner in the future life in which they believed - the happy hunting grounds.

The find was made about two and a half feet beneath the surface in a sand formation which had preserved the skeletons in an unusually excellent condition for their age, a rock formation having been formed about the bories in some instances.

The reconstruction of the woman's skeleton leads to the belief that she was more than six feet tal1, strong and well built. The skull is at least a third larger than present date sizes and has absolutely no forehead.

Mr. Nowotny believes that the skeletons are those of a very early type of man, probably more than 1500 years old, and considers the find one of the most interesting in his entire experience. Considerable interest is being manifested by scientists and archaeologists.

* Reprinted from the New Braunfels Herald, Vol. 38, No. 32, Friday, July 26, 1929, pp. 1 and 8. Our thanks to Mr. Oscar Haas of New Braunfels for securing copies of this article for the Center for Archaeological Research. 